\title{
PERKEMBANGAN PENDIDIKAN ISLAM DI NUSANTARA: MALAYSIA DAN INDONESIA
}

\author{
Rahimah Embong \\ Universiti Sultan Zainal Abidin, Malaysia \\ E-mail: rahimahembong@unisza.edu.my
}

\begin{abstract}
Abstrak: Penjajahan Barat telah banyak mempengaruhi pendidikan Islam di kebanyakan negara Islam di dunia. Modenisasi dan sekularisme adalah dua nilai barat yang membawa perubahan kepada model asas, konsep, dan prinsip pendidikan Islam. Makalah ini bertujuan untuk meneroka perkembangan pendidikan Islam dalam menghadapi kedua-dua nilai tersebut, bermula dari kemunculan Islam sehingga masa kini di Nusantara, dengan berfokus hanya kepada Malaysia dan Indonesia. Kajian ini mendapati perkembangan pendidikan bagi umat Islam di Malaysia dan Indonesia telah menunjukkan perubahan yang progesif serta penerapan nilai-nilai modenisasi dan sekularisme dalam sistem pendidikan sehingga terwujudnya dualisme. Walau bagaimanapun, kedua-dua aliran pendidikan (agama dan sekular) masih kekal terpisah di kebanyakan negara Islam sehingga kini. Justeru, perlunya kepada perancangan dan perlaksanaan kurikulum bersepadu yang bersifat Islamik yang sebenar. Usaha penyepaduan kurikulum dalam sistem pendidikan Islam bukan tugas yang mudah kerana memerlukan komitmen dan usahasama daripada pelbagai pihak.
\end{abstract}

Kata Kunci: pondok pesantren, nusantara, pendidikan Islam 


\section{PENDAHULUAN}

$\mathrm{P}$ endidikan Islam pada era moden telah banyak dipengaruhi oleh tindak balas umat Islam terhadap penjajahan Barat serta cabaran-cabarannya seperti modenisasi dan sekularisme. Penglibatan penjajah dalam sistem pendidikan menyebabkan permasalahan dikotomi ke atas masyarakat Islam dan sistem pendidikannya. Lantaran itu, era moden menyaksikan kebangkitan ramai tokoh reformasi Muslim seperti Jamal al-Din alAfghani (1839-97 AD), Syaikh Muhammad 'Abduh dari Mesir (1849-1905 AD), Rashid Rida (1865-1935), Sir Sayyid Ahmad Khan (d.1898A.D.), Sir Sayyid Amir Ali (d 1928 AD), Altaf Husayn Hali dan Muhammad Iqbal di benua kecil India, Cevdet Pasa dan Namik Kemal di Turki, Shaykh Abdul Hadi di Malaysia serta ramai lagi tokoh-tokoh reformasi (Rahimah, 2019).

Kepulauan atau Alam Melayu atau dikenali juga sebagai Nusantara, menerima kedatangan agama Islam sejak awal abad pertama Hijrah (kurun ketujuh Masehi) melalui peniaga Arab, terutamanya dari Yaman. Orang-orang Yaman telah memeluk agama Islam pada zaman Nabi Muhammad (s.a.w.) apabila baginda mengirim 'Ali r.a. dan Mu'adh Ibn Jabal ke sana untuk berdakwah tentang Islam. Di Nusantara, Islam tersebar luas dan sepenuhnya sebelum penghujung abad kelapan Hijrah. Tempoh masa antara abad ketujuh dan kelapan Hijrah (kurun ketiga belas dan keempat belas Masehi) merupakan era Islamisasi di rantau ini (Rauf, 2001). Walaupun Malaysia dan Indonesia mempunyai perkaitan yang rapat daripada segi bangsa, budaya dan warisan sejarah, tetapi masih terdapat perbezaan daripada aspek sejarah perkembangan pendidikan Islam ini. Oleh itu, kedua-dua negara ini perlu dibincangkan secara berasingan terlebih dahulu.

\section{Sejarah Pendidikan Islam di Malaysia}

Menurut sejarah di Malaysia, institusi pembelajaran agama telah berkembang daripada sekolah al-Qur'an yang tidak formal. Akhirnya, institusi ini berpusat menjadi sekolah agama tradisional yang dikenali sebagai 'pondok' yang mempunyai peranan yang berpengaruh dalam mendidik umat Islam Melayu pada awal abad keempat belas Masehi iaitu sebelum penjajahan dan juga semasa penjajahan (Che Noraini \& Langgulung 2008). Pondok-pondok ini dikendalikan oleh individu atau masyarakat. Teras pengajaran berdasarkan pada aliran mazhab Shafi'i dan Asy'ari. Kandungan kurikulum pondok-pondok ini tidak seragam, dan tempoh pengajiannya tidak terhad. Kebiasaannya beberapa subjek agama dipelajari seperti al-Quran, alSunnah, tauhid, fekah, sejarah Islam, 
tasawwuf dan akhlaq. Sesetengah pondok mengajar ilmu dalam bahasa Arab seperti nahu dan sarf, asas aritmetik dan logik (mantiq), tetapi tidak dalam bidang ilmu aqli. Kurikulum pondok ini biasanya berpusatkan mata pelajaran dan metodologi pengajaran lebih cenderung kepada kaedah hafalan (Rahimah, 2019).

Perkembangan positif terjadi dalam sejarah pendidikan Melayu sebagai impak reformasi yang diketuai oleh al-Afghani dan 'Abduh, terutamanya semasa pasca Perang Dunia Pertama pada awal abad kedua puluh. Anatara tokoh reformasi Melayu ialah Shaykh Tahir Jalaluddin, Shaykh Ahmad alHadi, Tuan Guru Muhammad Yusof bin Ahmad (1868-1933 A.D.). Sesetengah orang Melayu Islam menyedari bahawa sistem pondok tidak dapat mendepani cabaran pemodenan disebabkan oleh kurikulum yang terhad kepada subjek agama semata-mata. Bagi mengatasi cabaran tersebut, beberapa pondok telah ditransformasi menjadi institusi madrasah. Beberapa madrasah baharu telah ditubuhkan sebagai alternatif kepada sistem pondok. Pada tahun 1916, Madrasah al-Mas'hur al-Islamiyyah ditubuhkan oleh al-Hadi di Pulau Pinang. Madrasah ini menggunakan bahasa Arab sebagai bahasa pengantar, menawarkan pengajaran subjek Fekah beserta subjeksubjek sekular. Madrasah ini menggalakkan aktiviti-aktiviti pelajar seperti debat dan pidato. Sistem Madrasah lebih komprehensif dan kurikulumnya merangkumi banyak subjek seperti bahasa Arab, matematik dan geografi (Che Noraini \& Langgulung 2008).

Muhammad Yusof atau yang lebih dikenali sebagai Tok Kenali telah mengasaskan satu lagi sistem madrasah di Kelantan yang dipanggil sebagai Pondok Tok Kenali. Beliau ialah pengikut Shaykh Wan Ahmad al-Fatani yang mendapat inspirasi daripada al-Afghani dalam membebaskan umat Islam daripada penjajahan Barat. Beliau juga dipengaruhi oleh karya al-Ghazali terutamanya Ihyā' 'Ulum al-Dīn. Subjek-subjek yang diajar ialah bahasa Arab dan nahu, tawhid, Fekah, tafsir dan tasauwuf. Pondok ini menjadi popular dan menerima pelajar-pelajar daripada pelbagai negara. Seterusnya, rangkaiannya tersebar hingga ke Selatan Thailand, Sumatera, Pattani dan Indonesia (Wan Mazwati 2007).

Sesetengah pondok ditutup kerana menolak transformasi kepada madrasah, dan tidak berupaya menghadapi arus modernisasi. Madrasah tertentu mengekalkan kurikulum agama mereka. Kebanyakan kurikulum di pondok atau madrasah mengikut Al-Azhar dan institusi pengajian agama Timur Tengah yang lain. Sebahagian sijil-sijil mereka tidak diiktiraf oleh kerajaan dan di pasaran kerja semasa. Ini mengakibatkan kemerosotan sistem madra- 
sah di Malaysia pada tahun 1960-an. Mereka juga menghadapi pelbagai masalah dalaman seperti prestasi graduan yang agak rendah (Rosnani, 2004). Mereka ada juga menghadapi masalah kewangan yang menyebabkan sebahagian pondok dan madrasah ditutup.

\section{Sejarah Pendidikan Islam di}

\section{Indonesia}

Sepertimana di Malaysia, pendidikan agama Islam di Indonesia diperoleh daripada sekolah al-Qur'an tempatan serta sekolah berasrama Islam yang dipanggil pesantren. Pesantren menawarkan pendidikan untuk pelajar yang disebut santri dan mengamalkan sistem berpusatkan kyai. Kyai merupakan seorang ilmuwan agama tempatan yang terlibat dalam penubuhan dan pengajaran di pesantren serta menjadi pemimpin masyarakat Islam setempat. Kyai juga adalah seorang individu yang berpegang teguh pada ajaran agama serta berupaya mengeluarkan pendapat dan fatwa dalam hal agama serta mengendalikan majlis-majlis keagamaan. Biasanya pesantren terletak di tanah pertanian wakaf di kawasan luar bandar. Pesantren adalah satu-satunya sistem pendidikan yang terdapat di Jawa sehingga abad ke-20. Sistem ini diwarisi dari zaman agama Hindu dan agama Buddha. Pada awal abad ke-13, sistem ini telah melalui proses Islamisasi dan mula menawarkan kurikulum agama, pembelajaran al-Quran, bahasa Arab dan adat orang Islam dengan tujuan menghasilkan muslim yang baik (Lukens-Bull, 2003) serta melatih kader agamawan.

Akhirnya, sebahagian pesantren terpaksa diubah menjadi madrasah untuk menghadapi cabaran penjajahan Belanda. Selepas kemerdekaan, pemerintah telah melaksanakan sistem pendidikan nasional sebagai dasar pembangunan negara melalui pengajaran bahasa kebangsaan, Pancasila, sains dan matematik. Bagaimanapun, sesetengah orang Islam Indonesia menolak penekanan terhadap Pancasila menyebabkan mereka lebih memilih pendidikan di pesantren berbanding sekolah umum kebangsaan. Seterusnya, pemerintah Suharto menggesa penerapann kurikulum kebangsaan dan pembangunan modal insan dalam pendidikan Indonesia. Hal ini menyebabkan sebahagian pesantren mengintegrasikan pendidikan agama dan sekular serta menekankan pembangunan sahsiah dan latihan kemahiran. Mereka berhasrat untuk menghasilkan keperibadian yang mampu menguruskan kehidupan moden dengan mengamalkan nilai-nilai Islam (Lukens-Bull, 2003). Oleh itu, kurikulum pesantren telah berubah mengikut keperluan semasa supaya mampu menghadapi era modenisasi dengan cara Islam. Pada dasarnya, kurikulum agama meliputi pembelajaran al-Quran, bahasa 
Arab, shari'ah dan tradisi serta sejarah Islam.

Selain mengguna pakai kurikulum kebangsaan, sesetengah pesantren juga menawarkan kursus tambahan seperti bahasa Inggris, kemahiran komputer dan latihan kemahiran vokasional seperti kelas pemanduan, membaiki otomobil, jahitan, perusahaan kecil dan kimpalan. Akibatnya, muncul dua jenis pesantren, iaitu tradisional (salaf) dan moden (khalaf). Pesatren salaf kebiasaanya menggunakan kaedah tradisional dalam pengajaran agama yang dikenali sebagai sorogan dan wetonan; dan ia bergantung kepada ilmuawan agama untuk pembangunan kurikulum. Sementara kaedah pengajaran pesantren khalaf lebih menyerupai sistem nasional yang diamalkan oleh madrasah (Harsanto 2003).

Pengenalan sistem madrasah ini merupakan perubahan dinamik dalam pendidikan Islam yang dilaksanakan oleh Depatmen Hal Ehwal Agama yang didominasi oleh Muslim. Sistem baharu ini bertujuan untuk menghadapi cabaran zaman moden dan kehendak ibu bapa yang tidak berpuas hati dengan sistem negeri yang ada. Walau bagaimanapun, status madrasah lebih rendah daripada pesantren. Kemudian bagi membolehkan graduan melanjutkan pengajian mereka di sekolah-sekolah awam, beberapa perubahan telah dibuat oleh pemerintah. Ini termasuk menerima standard madrasah sebagai sama dengan sekolah-sekolah umum, meningkatkan bilangan pelajar madrasah untuk memasuki sekolah-sekolah awam yang setara di setiap peringkat dan mengiktiraf sijil madrasah swasta (Che Noraini \& Langgulung 2008).

Pada awal tahun 1990an, sistem madrasah telah mengintegrasikan mata pelajaran agama gaya pesantren dengan subjek sekular nasional. Ekoran daripada kualiti pengajaran yang baik, sekolah Islam menjadi lebih popular. Akibatnya, dua bentuk madrasah timbul, iaitu madrasah umum dan madrasah diniyyah. Yang pertama adalah sama dengan sekolah-sekolah awam yang menggunakan kurikulum nasional tetapi mengekalkan nilai-nilai sekolah Islam. Yang kedua mengintegrasikan sistem madrasah dan pembelajaran gaya pesantren untuk melengkapi kurikulum nasional dan pengajian agama (Amr Abdalla et al, 2006). Sesungguhnya integrasi ini dibuat untuk melahirkan pemimpin yang mendokong kedua-dua identiti iaitu kebangsaan dan Islam.

\section{Reaksi Ilmuwan Melayu Islam}

Dalam sejarah Nusantara, sistem pendidikan untuk Melayu Islam bersifat keagamaan yang telah dibangunkan terutamanya oleh para ilmuwan agama yang disegani. Perkembangan pendidikan Islam yang ketara di Nusantara bermula pada awal abad kedua puluh Masehi, ekoran daripada 
hubungan dengan reformasi Islam dari Timur Tengah terutamanya Mesir dan keperluan untuk menangani cabaran modernisasi daripada penjajahan Barat. Perbezaan dalam pemikiran atau idealogi telah mengakibatkan pemecahan atau dikotomi dalam kalangan ilmuwan agama Melayu kepada dua golongan utama, iaitu konservatif dan progresif. Kategori Melayu yang progresif dipengaruhi oleh tokoh reformasi Islam terutamanya Sheikh Jamaluddin al-Afghani, Sheikh Muhammad 'Abduh dan Rashid Rida. Pemikiran mereka yang sangat optimis mempengaruhi pemikiran orang Melayu serta menjadikan mereka lebih kritis dan kreatif (Rahimah,2019).

Di Tanah Melayu atau kini dikenali sebagai Malaysia, kumpulan konservatif, yang menentang perubahan, dipanggil sebagai 'Kaum Tua' manakala kumpulan progresif, yang memilih pembaharuan, dikenali sebagai 'Kaum Muda'. Para pemimpin progresif memperjuangkan aspirasi mereka melalui majalah-majalah dan menubuhkan sistem pendidikan Islam moden yang dinamakan madrasah. Penubuhan madrasah ini telah telah merangsang semangat reformasi Islam. Mereka bercitacita untuk mewujudkan masyarakat Islam yang progresif. Seterusnya di Indonesia, perjuangan antara konservatif dan progresif dtelah iinstitusikan melalui penubuhan kumpulan reformasi Muhammadiyah pada tahun 1912, mewakili pemikiran rasionalisme progresif kontemporari yang terdiri daripada graduan universiti al-Azhar, Mesir. Manakala, gerakan Jawa yang dikenali sebagai Nahdat al-'Ulama' telah ditubuhkan pada tahun 1926 untuk memelihara doktrin ortodoks yang didokongi oleh mereka yang mempunyai pengalaman atau pendidikan dari Makkah atau Madinah

Selepas era penjajahan, terdapat tiga golongan ilmuawan Muslim yang wujud di kebanyakan negara Islam akibat reaksi mereka terhadap pemodenan Barat. Isu kemunduran umat Islam menjadi isu utama perbahasan dalam kalangan mereka dengan menjelaskan faktor dan solusi masingmasing. Golongan pertama adalah ilmuwan berfikiran sekular yang majoriti graduan dari negara-negara Barat yang berpendidikan sekular. Mereka mengandaikan agama Islam dan ulama agama sebagai faktor kemunduran serta berpendapat adoptasi keseluruhan modernisasi Barat dan sekularisasi sebagai solusi terbaik. Di sudut lain, golongan kedua bersifat konservatif agama atau fundamentalis yang yakin bahawa umat Islam telah menyimpang daripada jalan Islam yang sebenar. Oleh itu, umat Islam perlu kembali meninjau tradisi peradaban Islam. Mereka percaya bahawa modenisasi telah menjejaskan doktrin Islam. Mereka tekad menolak sebarang ilmu pengetahuan 
moden sekular, dan membenarkan pemisahan sistem agama dan sistem moden. Hal ini menimbulkan dilema kepada masyarakat. Akhirnya, muncul golongan ketiga, para ilmuwan bersifat sederhana yang tidak menyalahkan ajaran agama Islam tetapi berpendapat bahawa sikap tertutup ilmuwan dan kejumudan sistem pendidikan Islam yang sedia ada boleh menyumbang kepada kemunduran umat Islam. Oleh itu, mereka lebih menyokong adaptasi arus pemodenan mengikut paradigma Islam.

\section{Dualisme dalam Sistem Pendidikan}

Sebelum kedatangan penjajah, pendidikan al-Quran dan agama adalah satusatunya sistem pendidikan di dunia Islam yang diwarisi daripada tradisi Nabi s.a.w. Mereka memanfaatkan masjid sebagai pusat pembelajaran. Dualisme pendidikan mula berkembang secara ketara semasa penjajahan Barat di kebanyakan negara Islam.

Di Alam Melayu, penjajah melaksanakan sistem pendidikan sekular moden untuk mendoktrinasi minda orang Islam. Walau bagaimanapun, sistem sekular tidak memansuhkan sistem dan institusi pendidikan tradisional Islam yang sedia ada. Hal ini mengakibatkan wujudnya dualisme dalam pendidikan iaitu sistem sekular moden dan sistem agama tradisional. Sistem pertama merupakan kesinambungan sistem penjajah, yang bertujuan untuk melatih penjawat awam dan teknokrat dalam bidang sains dan teknologi. Sesungguhnya ini menjadi cabaran kepada sebahagian pengamal pendidikan agama tradisional yang terpaksa berubah demi kelangsungan mereka. Sesetengah ilmuwan mengkritik sekolah-sekolah sekular Barat termasuklah sekolah mubaligh yang memberi ancaman terhadap kepercayaan dan amalan umat Islam (Rahimah, 2019).

Golongan reformis Islam mengkritik sistem pendidikan agama tradisional kerana objektif dan kandungan kurikulum yang sempit. Sistem ini dianggap menghasilkan graduan yang kurang berdaya saing yang pakar dalam soal agama sahaja (Rosnani 2004). Akhirnya, para reformis menyeru transformasi sistem pembelajaran tradisional ke arah yang lebih moden. Di Malaysia sebagai contohnya, Tok Kenali (18681933M / 1287-1352H) merupakan perintis sistem pendidikan bersepadu dan beliau menubuhkan sekolah dengan kurikulum bersepadu. Beliau melihat orang Melayu mundur kerana kurang berilmu dalam pengetahuan moden, yang dianggapnya penting untuk pembangunan fizikal. Menurut beliau, umat Islam perlu mempelajari kedua-dua ilmu pengetahuan agama dan pengetahuan manusia (Wan Mazwati 2007).

Kenyataannya sekolah Islam bersepadu, sejenis institusi pendidikan formal di 
peringkat pra-universiti yang ditubuhkan dan terdiri daripada pesantren dan madrasah yang berkembang pesat seiring dengan sekolah moden umum dan institusi pendidikan Islam. Di Malaysia, peranan sistem pondok dilihat lebih konservatif. Sistem ini menekankan penerangan dan penyebaran kepercayaan dan amalan agama Islam benar yang dipelopori oleh aliran akidah Ash'ari dan mazhab fekah Shafi'ite. Sebaliknya, madrasah memainkan peranan yang lebih dinamik dalam menghidupkan semula intelektualisme Islam dan menyampaikan persepsi inovatif terhadap pemodenan. Sistem madrasah bertujuan membangunkan umat Islam yang mahir dalam kedua-dua ilmu pengetahuan moden dan agama sekaligus mempersiapkan pelajar dengan kemahiran hidup (Rahimah, 2019).

Di Indonesia, walaupun sistem pesantren dan pemodenan dianggap serasi, namun ia perlu digandingkan bersama-sama untuk memenuhi kepentingan sosial. Lukens-Bull (2003) mendakwa bahawa pesantren Jawa menjadi contoh dalam mewujudkan sistem pendidikan hibrid dengan penyepaduan pendidikan agama dan persediaan teknikal saintifik, yang menggambarkan model sistem Islam yang unik dan reaksi terhadap pemodenan melalui pendekatan afirmatif. Sistem madrasah Indonesia menggunakan sistem pendidikan moden dan kurikulum kebangsaan. Namun, madrasah hanya memiliki kemudahan yang terhad dan mereka mengambil pelajar daripada golongan yang kurang bernasib baik dan kelas menengah rendah.

\section{PENUTUP}

Beberapa perubahan perlu dibuat untuk memodenkan sistem pendidikan Islam. Pertamanya, menggunakan kemudahan fizikal seperti kerusi dan meja; kedua, memasukkan subjek bukan agama dalam kurikulum formal; ketiga, menggunakan metodologi pengajaran yang inovatif; keempat, menggunakan alatan dan bahan teknologi moden sebagai alat bantu mengajar; dan kelima, megamalkan kebebasan berfikir dan fleksibiliti dalam pemikiran. Faktor terakhir ini penting bagi mengatasi isu kebekuan intelektual pada era moden. Dari satu sudut, modernisasi merupakan usaha penyepaduan pembaharuan dalam sistem pendidikan Islam. Dari sudut lain pula, usaha mengintegrasikan kedua-dua kurikulum sekular dan agama tidak dapat direalisasikan sepenuhnya disebabkan maklum balas yang pesimis daripada beberapa orang pendidik Islam. Akibatnya, kedua-dua sistem pendidikan masih terpisah di dunia Islam hinga kini. Justeru, perlunya kepada perancangan dan perlaksanaan kurikulum bersepadu megikut paradigma Islamik dalam konteks yang sebenar. Usaha 
Rahimah Embong- Perkembangan Pendidikan Islam...

penyepaduan kurikulum dalam sistem pendidikan Islam bukan tugas yang mudah kerana memerlukan komitmen dan usahasama daripada pelbagai pihak.

\section{RUJUKAN}

Abdul Rauf, Muhammad. (2001). The Muslim Mind: A Study of the Intellectual Muslim Life during the Classical Era (701-1200 A.H./13001768 A.D.). Kuala Lumpur: Dewan Bahasa dan Pustaka.

Amr Abdalla; Muhammed Abu-Nimer; Ilham Nasser; Aysa Kadayific; Lynn Kunkle and Saber el-Kilani. (2006). Improving the Quality of Islamic Education in Developing Countries: Innovative Approaches. Washington D.C.; Creative Associates International, Inc.

Che Noraini Hashim \& Hasan Langgulung.(2008) “Islamic Religious Curriculum in Muslim Countries: The Experiences of Indonesia and Malaysia." Bulletin of Education \& Research 30, no. 1 ,
Harsanto, Damar. (February 7, 2003). Orthodox 'Pesantren' Evolves into Modern School. Jakarta Post.

Lukens-Bull, Ronald A. (2003). “Teaching Morality: Javanese Islamic Education in a Globalizing Era." Journal of Arabic and Islamic Studies, 3. Pp.26-47.

Rahimah Embong. (2019). Educational Dualism In The Muslim World History and Issues. Penerbit UniSZA. Kuala Terengganu.

Rosnani Hashim.(2004). Educational Dualism in Malaysia: Implications for Theory and Practice, 2nd edn. Kuala Lumpur: The Other Press.

Wan Mazwati Wan Yusoff. (2007). "The Educational Thoughts and Practices of Muhammad Yusof bin Ahmad (Tok Kenali)." Jurnal pendidikan Islam 12, no. 2 . 
Jurnal TAMADDUN - FAI UMG. Vol. XXI. No.1 / Januari 2020 